\title{
Full mouth rehabilitation with dental implant utilizing 3D digital image and CAD/CAM system: case report
}

\author{
Se-Ha Kang', Seung-Mi Jeong ${ }^{1 *}$, Jae-Ok Shin', Jeong-Whan Fang', Dae-Hwan Kim¹, Byung-Ho Choi ${ }^{2}$ \\ 'Department of Prosthodontics, Wonju College of Medicine, Yonsei University, Wonju, Republic of Korea \\ ${ }^{2}$ Department of Oral and Maxillofacial Surgery, Wonju College of Medicine, Yonsei University, Wonju, Republic of Korea
}

This article describes how to use digital system in a fully edentulous case that diagnosis to definitive prosthesis fabrication. While proceeding oral scan and CBCT taking, digital markers were attached on maxillary palate and lower existing denture. Using CBCT image and oral scan image, the bone contour and anatomical structures were analyzed and flapless surgical guide, customized abutment and prosthesis were made. After the osseointegration, the definitive prosthesis was fabricated using the oral scan image with scan body. It provides clinicians with a fast workflow and improves clinical efficiency. (J Dent Rehabil Appl Sci 2015;31(2):15868)

Key words: full edentulous; full mouth rehabilitation; CAD/CAM, flapless implant surgery; oral scan; digital system

\section{서론}

임플란트와 관련한 기술은 그 동안 많은 발전을 이루 어 왔다. 개발 초기에는 임플란트의 골유착과 생존율에 초점이 맞춰졌다면 최근에는 골유착은 기본적인 요구 사항이고, 이상적인 보철물 제작을 위한 정확한 식립 위 치, 최소 침습적이고 편안한 진료, 내원 횟수의 감소 등 에 초점이 맞춰지고 있다. 구강스캐너와 같은 디지털 이 미지 기술 및 CAD/CAM (Computer-aided design / Computer-aided manufacturing)의 발전, CBCT (Cone Beam Computed Tomography)의 보급은 임플란트 분야 에서 상기의 목적을 달성할 수 있게 하였다. ${ }^{1-3}$ 이러한 디 지털 이미지 기술 활용의 첫 번째 단계는 촬영된 구내 이 미지와 $\mathrm{CBCT}$ 이미지와의 중첩이다. 유치악 환자에서

*Correspondence to: Seung-Mi Jeong Professor, Department of Prosthodontics, Wonju College of Medicine, Yonsei University, 20 Ilsan-ro, Wonju, 220-701, Republic of Korea Tel: +82-33-741-1435, Fax: +82-33-741-1442, E-mail: smj3@yonsei.ac.kr Received: May 22, 2015/Last Revision: June 10, 2015/Accepted: June 11, 2015
는 치아를 이용하여 중첩을 진행하지만 무치악의 경우에 는 치아를 중첩에 이용할 수 없기 때문에 인상을 채득하 여 석고모형을 제작하거나 의치복제를 통해 방사선 불투 과성 마커를 가진 레진 템플레이트를 제작하여 CBCT를 촬영해왔다. 이 경우 수작업에 의한 제작이 이루어지고 내원 횟수도 늘어나며 제작과정 중 오차가 필연적으로 발생하였다. ${ }^{47}$ 이러한 문제를 해결하고자 본원에서는 방 사선 불투과성 마커를 구개부와 의치에 부착하여 연조직 스캔 이미지와 CBCT 이미지를 효과적으로 중첩하는 방 법을 개발해왔다. 본 증례에서는 완전 무치악 환자에서 디지털 기술과 $\mathrm{CAD} / \mathrm{CAM}$ 을 이용하여 3차원 디지털 이 미지를 중첩하고 이를 통해 top-down 개념의 수술가이 드, 즉시보철물 및 최종보철물 제작에 관한 방법을 제시 하고자 한다.

Copyright@ 2015 The Korean Academy of Stomatognathic Function and Occlusion. (c) It is identical to Creative Commons Non-Commercial License. 


\section{증례 보고}

본 증례의 환자는 56 세 여성으로 의치가 불편하고 사 용하기 어려워 임플란트 식립을 원한다는 주소로 내원 하였다(Fig. 1). 전신질환으로는 고혈압 병력이 존재하였 다. 상 하악 모두 완전 무치악 상태였으며 치과병력으로 는 과거 상 하악 후방연장 국소의치를 사용하였고, 최근 치주질환으로 전치부까지 발치하면서 상 하악 총의치 를 사용 중이었다. 치주질환으로 인한 발치병력으로 골 결손 부위가 좁은 치조제로 나타났으나 전반적인 치조 골 상태는 양호한 편이었다. 치료계획으로 임플란트 지 지 고정성 보철물과 임플란트 유지 피개의치를 고려하 였으며, 의치에 대한 거부감이 존재하였고 양호한 치조 골 상태, 환자의 요구를 고려하여 상 하악 임플란트 지 지 고정성 보철물을 계획하였다. 상악에는 8 개, 하악에 는 6 개의 임플란트를 식립하여 제 1 대구치까지 수복을 계획하였다.

임플란트 식립은 상악을 먼저 계획하였으며 상악의
임플란트 식립 및 임시 보철물 수복 후, 하악의 임플란 트 식립을 진행하였다. 상악의 임플란트 식립 위치 결정 및 수술 가이드 제작을 위해 먼저 상악 구개부위에 광중 합레진을 이용하여 4 개의 방사선 불투과성 마커를 부착 하였다(Fig. 2). 마커는 직경 $3 \mathrm{~mm}$, 높이 $3 \mathrm{~mm}$ 로 방사 선 불투과성 재료인 알루미나(alumina)로 만들어졌다. 마커 부착 후, 구강스캐너(Trios, 3Shape, Copenhagen, Denmark)로 상악 무치악 치조제와 구개부에 부착한 4 개의 마커를 스캔하였다(Fig. $3 \mathrm{~A}$ ). 구강스캔 후에는 마 커를 붙인 채로 CBCT (PointNix, Seoul, Korea)를 촬영 하였다. 교합고경의 결정 및 상 하악 악간관계채득을 위 해 알지네이트를 이용해 인상채득하고 석고모형 상에 서 교합제를 제작하였으며, 다음 내원 시 교합제를 이 용하여 수직교합고경의 결정 및 상 하악 악간관계채득 을 시행하였다. 악간관계가 기록된 석고모형을 교합기 (PROTARevo, KaVo, Leutkirch, Germany)에 부착 후 구강스캐너를 이용하여 스캔하여 대합치 및 악간관계에 대한 디지털 이미지를 얻을 수 있었다(Fig. 3B, 3C).

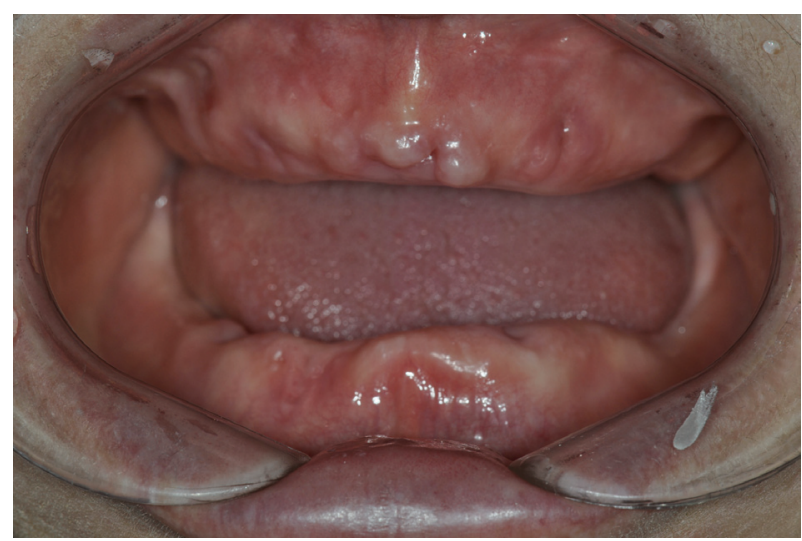

Fig. 1. Intraoral examination: maxillary and mandibular edentulous state.
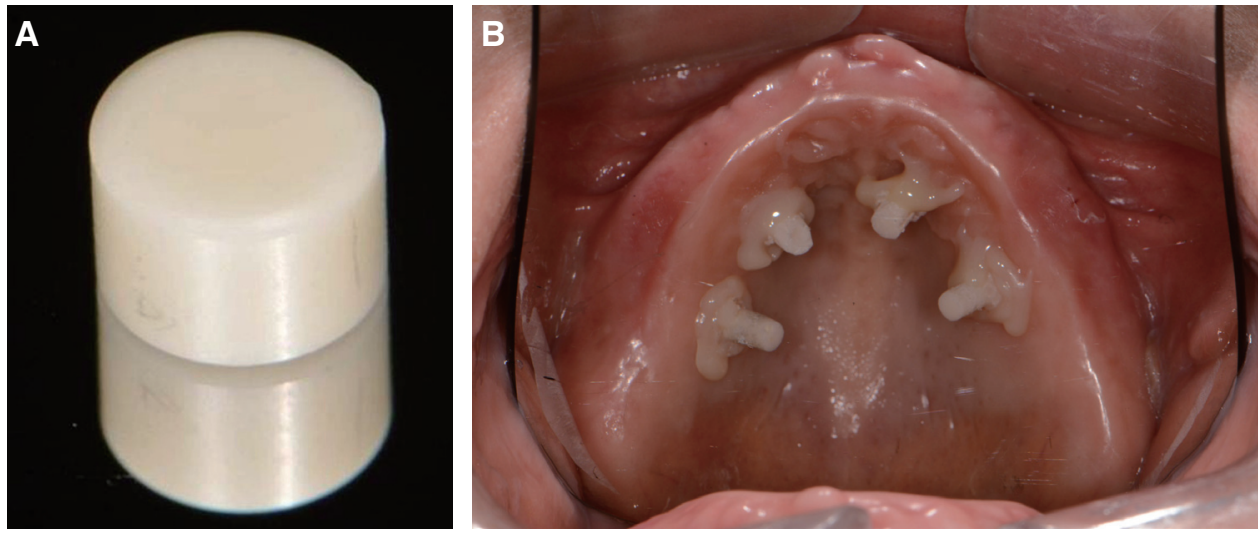

Fig. 2. Digital markers for maxillary scanning and $C B C T$ taking. (A) Digital marker, (B) Bonding 4 markers on palatal area. 

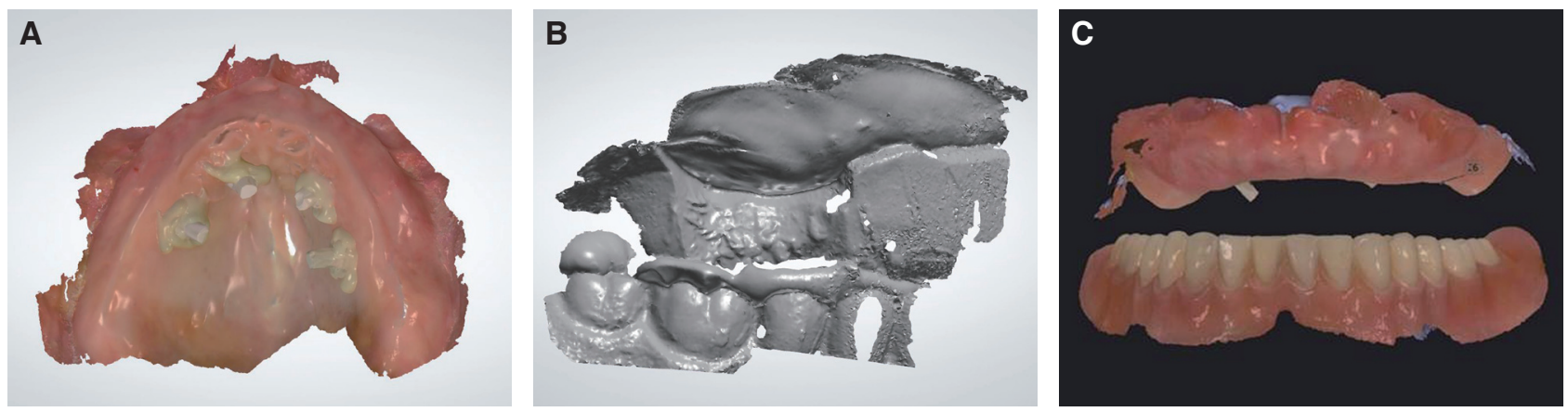

Fig. 3. Maxillary scanning procedure. (A) Intraoral scan image, (B) Bite scan image, (C) Intraoral image with vertical dimension and interocclusal relationship.
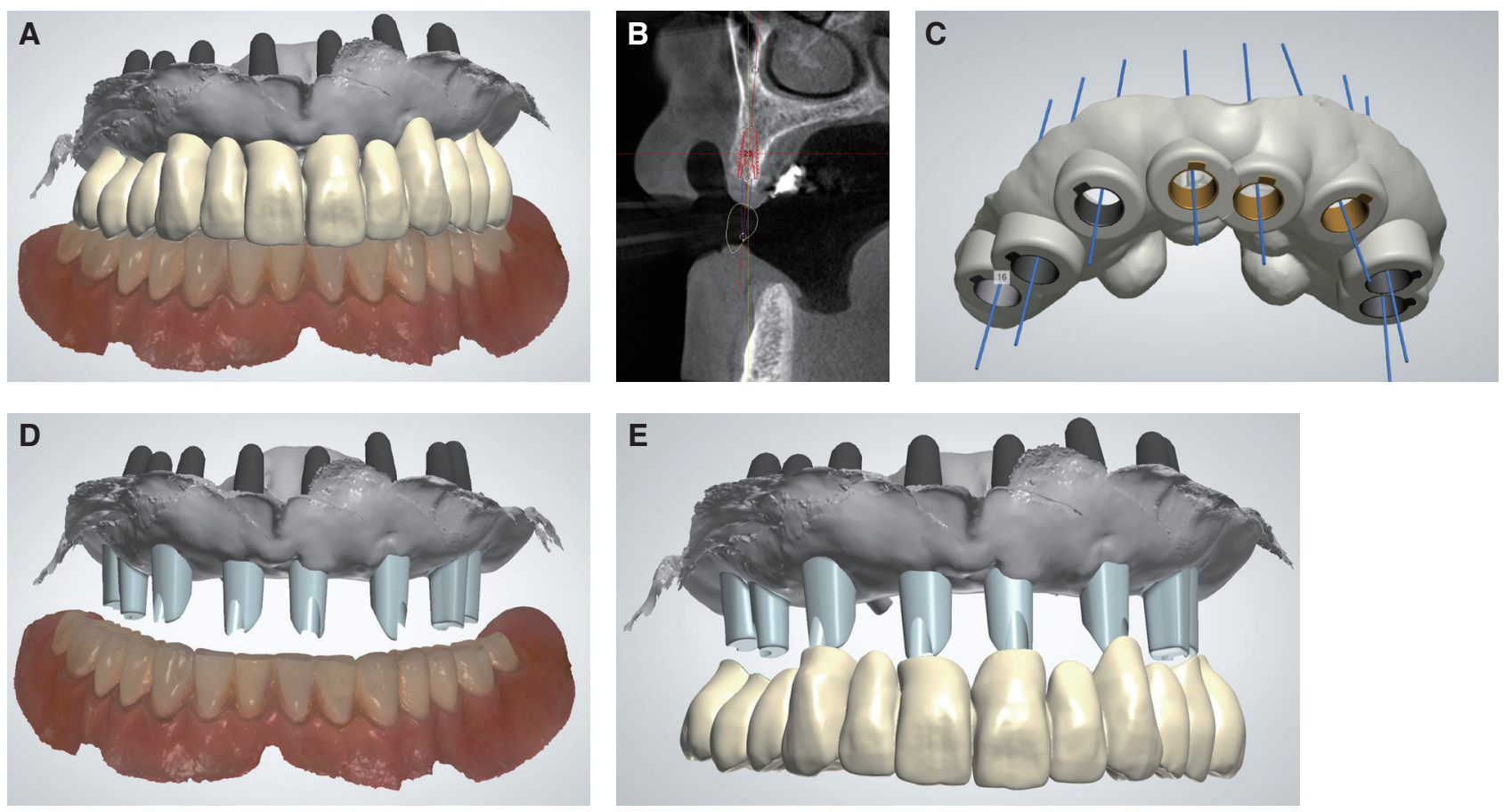

Fig. 4. Planning of implant placement. (A) Virtual wax up, (B) Positioning the fixture on CBCT image, (C) Surgical guide design, (D) Abutment design, (E) Temporary prosthesis design.

임플란트 식립을 위한 술전 분석 및 수술가이드와 임 시보철물 제작은 3차원 디지털 이미지를 이용하여 이루 어졌다. Implant studio 소프트웨어(3Shape)에서 상악에 위치시킨 마커를 기준으로 CBCT 이미지와 구내스캔 이 미지를 중첩하였다. 중첩 후 3Shape Dental System 소프 트웨어(3Shape)를 이용하여 top- down 개념에 맞춰 가상 의 치아배열(virtual wax up)을 하고, CBCT 이미지의 해 부학적 고려사항에 맞춰 임플란트의 식립 위치를 결정하 였다. 최종 식립 위치 결정 후, 교합면 이미지에서 임플란 트 중심축과 치관 사이 관계를 검증하였다. 이를 바탕으
로 수술가이드를 디자인하고 결정된 임플란트 위치에 즉 시보철을 위한 맞춤형 지대주와 임시치아를 디자인하였 다(Fig. 4). 수술가이드는 3D 프린터(Projet $3510 \mathrm{MP}, 3 \mathrm{D}$ Systems, Rock Hill, SC, USA)로 제작하고 가이드 내부에 금속 슬리브를 장착하였으며, 맞춤형 지대주와 임시치 아는 밀링기계(Arum 5축 밀링기계, Doowon, Daejeon, Korea)로 제작하였다. 추가적으로 수술가이드의 고정을 위해 석고모형상에서 퍼티 타입의 실리콘 인상재를 이용 하여 고정용 바이트를 제작하였다.

일련의 진단과정을 거쳐 제작된 수술가이드를 고정용 
바이트를 이용하여 환자 구강 내에 안정적으로 위치시 키고, 3개의 고정용 나사를 이용하여 환자의 상악에 고 정시켰다. 직경 $3 \mathrm{~mm}$ 의 연조직 펀치 드릴을 수술가이드 의 슬리브 내부로 넣고 회전시켜 연조직 부분을 제거 후, DIO 수술키트(DIO NAVI surgical kit, DIO Implant, Busan, Korea)를 이용하여 드릴링을 시행하였다. 모든 드릴은 상단에 stop을 가지며 이 stop이 수술가이드 상 단에 접촉할 때까지 드릴링을 시행하였다. 드릴링 후 상 악 양측 중절치, 견치, 제 2 소구치, 제 1 대구치 부위에 총 8개의 임플란트(UF II, DIO Implant)를 식립하였다. 계 획한 위치에 임플란트 식립 완료 후 수술가이드를 제거 하고 미리 제작된 맞춤형 지대주를 연결하고, 임시보철 물을 부착하였다(Fig. 5).
하악의 임플란트 식립을 위해 먼저 환자가 사용하고 있는 의치내면을 연성 임시이장재(COE-SOFT, GC, Chicago, USA)를 이용하여 첨상하여 의치내면이 치조 제 형태와 일치되도록 하고, 상악치아와 안정적인 관계 를 가지도록 조절하였다. 의치내면 첨상 후 3 개의 마커 를 광중합 레진을 이용하여 의치의 전치부 순측, 양측 구 치부 협측에 부착하였다. 의치 재장착 후 악간관계 채득 재료로 상 하악을 안정적으로 고정시킨 후 $\mathrm{CBCT}$ 를 촬 영하였다(Fig. 6). CBCT 촬영 후 상악을 알지네이트로 인상채득하고, 하악의치의 내면에 석고를 부어 석고모 형 제작 후, 교합기에 부착하였다. 석고모형에서 마커를 고정시킨 후 모델에서 의치만 제거하였다. 의치가 제거 된 상태에서 구강스캐너를 이용하여 상 하악과 악간관
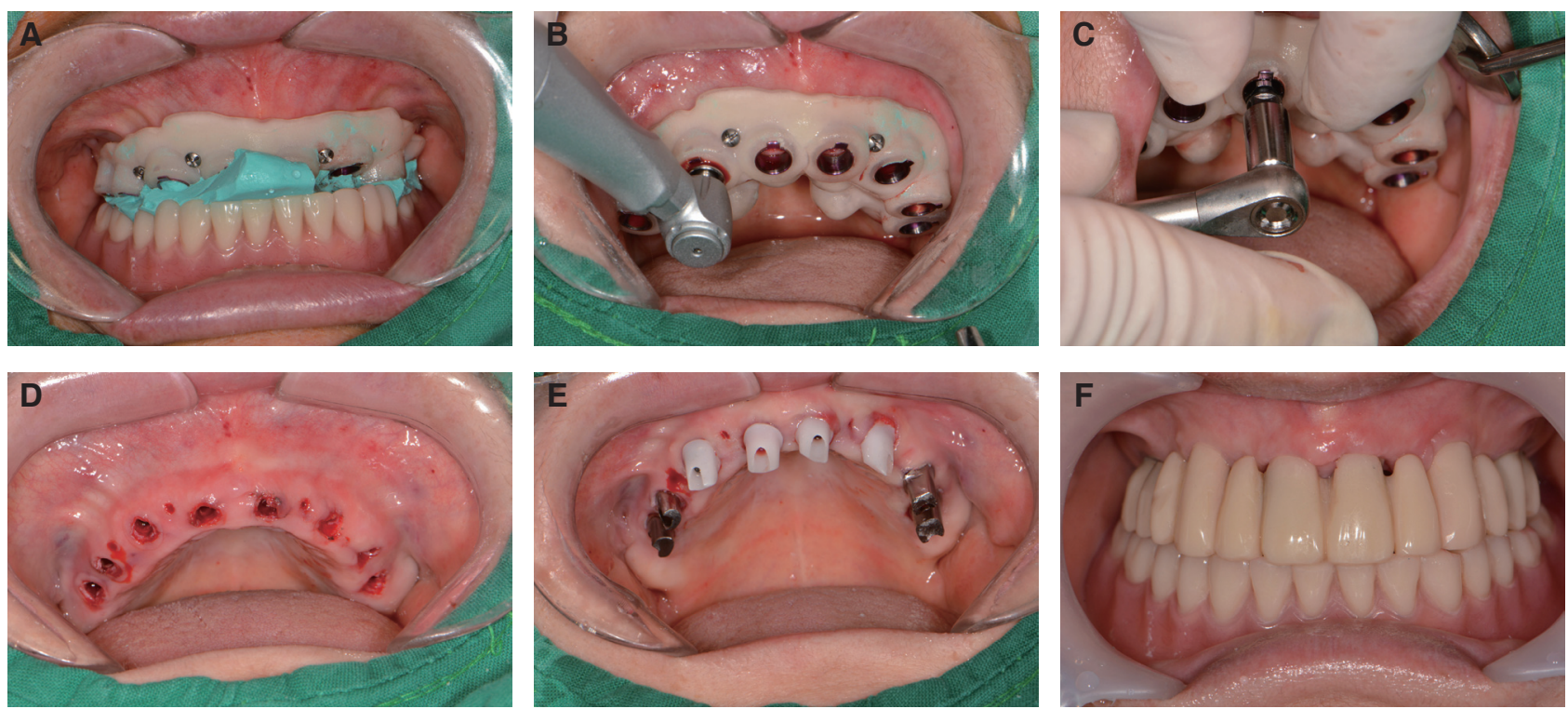

Fig. 5. Implant surgery on maxilla. (A) Surgical guide fixation with three stabilization screw, (B, C) Drilling by flapless implant kit, (D) Condition immediately after implant placement, (E) Temporary custom abutment placement, (F) Temporary prosthesis placement.
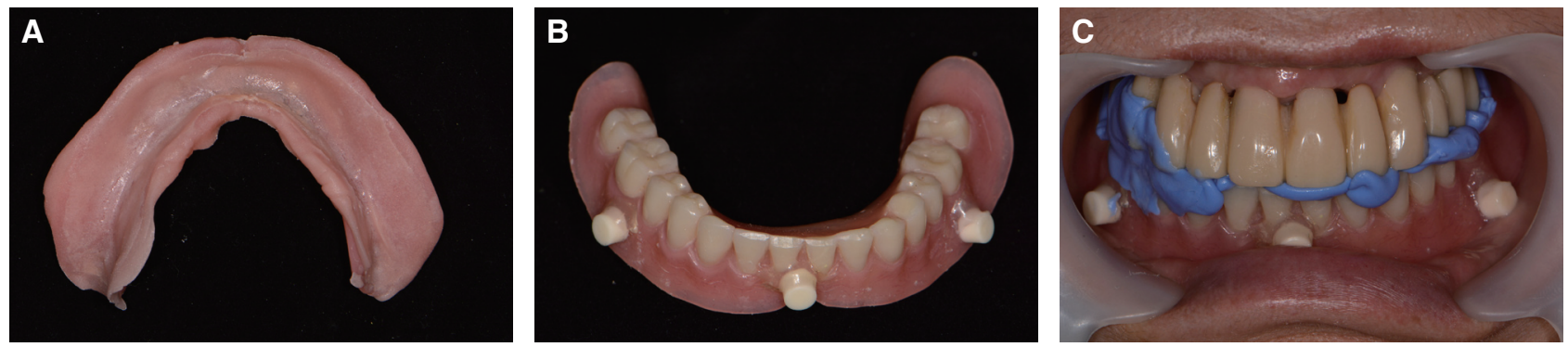

Fig. 6. Digital markers for mandibular CBCT taking. (A) Lining the mandibular denture, (B) 3 markers bonded to the denture, (C) Intraoral view of wearing the denture with digital markers. 
계를 스캔하였다(Fig. 7). 부착된 3개의 마커를 기준으로 스캔 이미지와 $\mathrm{CBCT}$ 이미지의 중첩을 시행하였다. 이 후 분석 및 디자인 과정은 상악과 동일하게 진행하였다.

상악과 마찬가지로 고정용 바이트를 이용하여 수술가 이드를 환자 구강 내에 안정적으로 위치시키고, 3 개의 고정용 나사를 이용하여 수술가이드를 환자의 하악에 고정시켰다. 직경 $3 \mathrm{~mm}$ 의 연조직 펀치 드릴과 $\mathrm{DIO}$ 수 술키트를 사용하여 드릴링을 시행하였으며, 드릴링 후
하악 양측 견치, 제 2 소구치, 제 1 대구치 부위에 총 6 개의 임플란트(UF II)를 식립하였다. 임플란트 식립 완료 후 수술가이드를 제거하고 미리 제작된 맞춤형 지대주를 연결하고, 임시보철물을 부착하였다(Fig. 8). 또한 임플 란트 식립 직후 $\mathrm{CBCT}$ 를 촬영하여 계획한 위치와 실제 임플란트 식립 위치가 일치하는 것을 확인하였다.

상악의 임플란트 식립 6개월 후, 최종보철물 제작을 진행하였다. 치근단 방사선사진을 통해 골수준이 유지
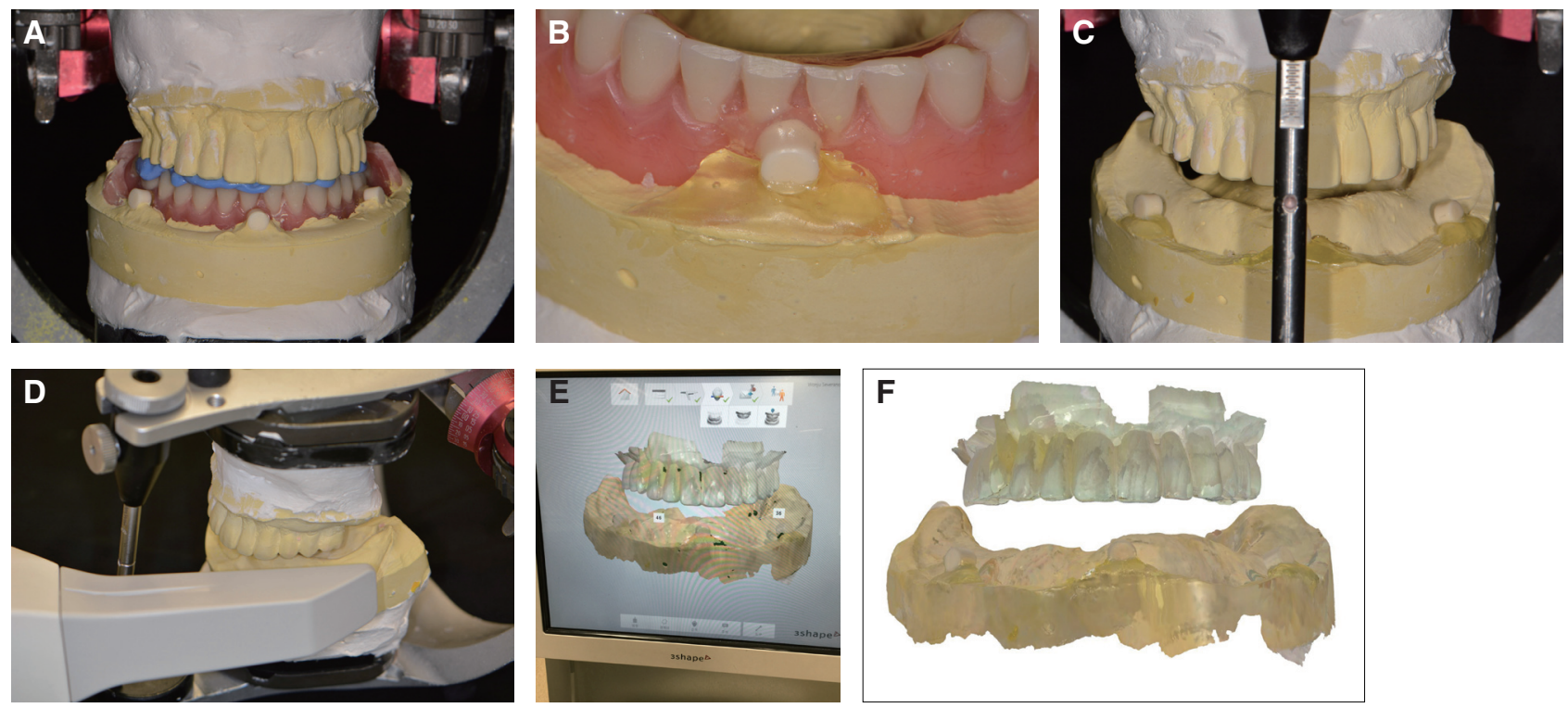

Fig. 7. Mandibular scanning procedure. (A) Pouring dental stone on lower denture and mounting stone cast, (B, C) Located digital marker on mandibular stone cast, (D) Bite scanning, (E, F) Image of interocclusal relationship.
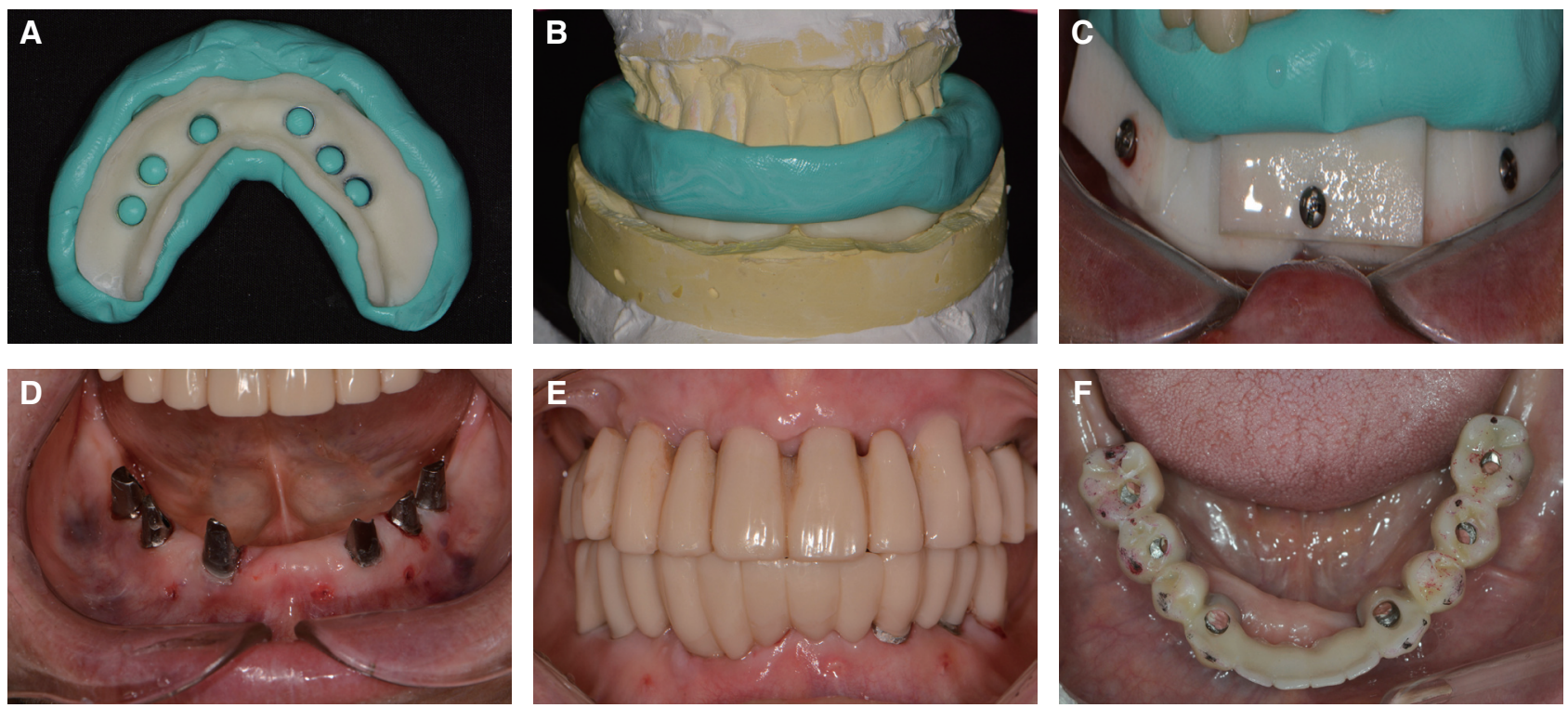

Fig. 8. Implant surgery on mandible. (A, B) Surgical guide fixation index, (C) Surgical guide fixation with three stabilization screw, (D, E, F) Condition immediately after temporary abutment and prosthesis placement. 
되는 것을 확인하였고, Periotest를 이용하여 골유착 상 태를 평가하였다. 임시보철물 사용기간 동안 하악에 한 번의 나사 풀림이 발생하였으나 충분한 임플란트의 고 정을 보였고, 구강위생관리와 연조직 치유 또한 양호하 였다. 디지털 방식을 이용한 최종보철물의 제작을 위해 구강스캐너를 계획한 디자인에 맞추어 세팅하고, 상 하 악의 임시보철물과 맞춤형 지대주 제거 후 연조직 스캔 을 먼저 진행하였고, 스캔바디(scan body)를 체결한 후 에 다시 한번 스캔을 진행하였다(Fig. 9A, 9B). 내부연결 형 임플란트인 점을 감안하여 스캔바디는 $35 \mathrm{Ncm}$ 으로 10 분 간격, 2 회 조였으며, 치근단 방사선사진으로 완전 한 체결을 확인 후에 스캔을 진행하였다. ${ }^{8}$ 임시보철물의 수직교합고경이 적절하다고 판단하여 교합스캔은 지대 주를 체결한 상태에서 임시치아를 절반씩 나누어 진행 하였다(Fig. 9C). 일반적인 교합스캔은 순측만 스캔하여 이루어지는 반면 본 증례에서는 교합면 부위까지 스캔 하는 방식으로 진행하여 중첩의 정확성을 높였으며, 중 첩에 도움이 되도록 연조직에 검은색 marking pencil로 표시 후 진행하였다. 짧은 길이를 교합스캔하는 경우에 는 자동 정렬이 되는 경우가 많으나 본 증례의 경우 자 동 정렬되지 않아 표시된 점과 해부학적 점들을 잡아 수 동 정렬하여 최종적인 악간관계를 얻었다.

3Shape Dental System 소프트웨어에서 스캔바디 를 통해 임플란트의 3차원적인 식립정보를 얻었다
(Fig. 9D). 가상의 치아배열을 통해 맞춤형 지대주와 치 관의 형태를 디자인하고, 소프트웨어의 가상 교합기 (PROTARevo, $\mathrm{KaVo}$ ) 기능을 이용하여 교합 및 가이드 를 조정하였으며 교합 양식은 전방, 측방 운동시 빠른 구치부 이개가 일어나도록 하는 상호보호 교합으로 형 성하였다(Fig. 10). 임플란트 식립 계획 시, 제1소구치 부 위의 골결손으로 임플란트 식립이 어려워 제 2 소구치 부 위에 식립을 결정하였으며, 보철물에 캔틸레버를 부여 하지 않으면서 추후 수리나 재접착 시의 편의성, 충분 한 연결고정 효과를 고려하여 상악은 2 분획으로, 하악 은 전악연결고정으로 최종보철물을 디자인하였다. 지 대주 재료는 하악관 상악 구치부의 경우 티타늄, 심미성 이 강조되는 상악 중절치, 견치의 경우 링크를 이용한 지르코니아로 선택하였다. 변연은 최종보철물이 SCRP (Screw-Cement Retained Prosthesis) 형태인 점과 환자 의 낮은 미소선을 고려하여 치은연상으로 형성하였다. 악간관계와 교합 및 안모의 최종 확인을 위해 상부 보철 물은 PMMA (Poly methyl methacrylate) 레진을 밀링하 여 임시보철물을 제작하였다.

최종지대주를 구강 내 시적한 결과, 변연의 위치와 보 철물의 삽입로 모두 양호하였다(Fig. 11). 지대주를 35 $\mathrm{Ncm}$ 로 조인 후, EZ-Seal (Megagen, Daegu, Korea)을 이용하여 나사구멍을 메웠다. 레진 임시보철물은 상 하악 모두 좋은 적합도와 안모, 교합을 보였으나 하악
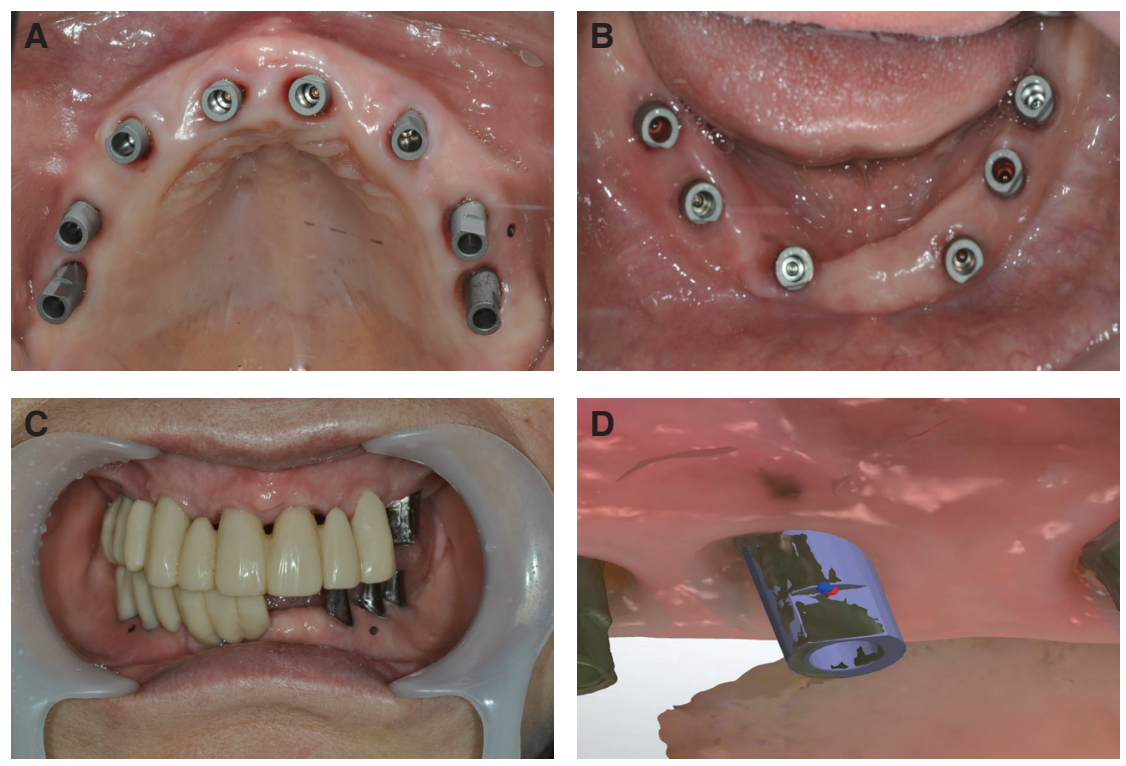

Fig. 9. Digital impression with scan body. (A, B) Intraoral view with scan body, (C) Bite scan using sectional temporary prosthesis, (D) Merging the scan body. 

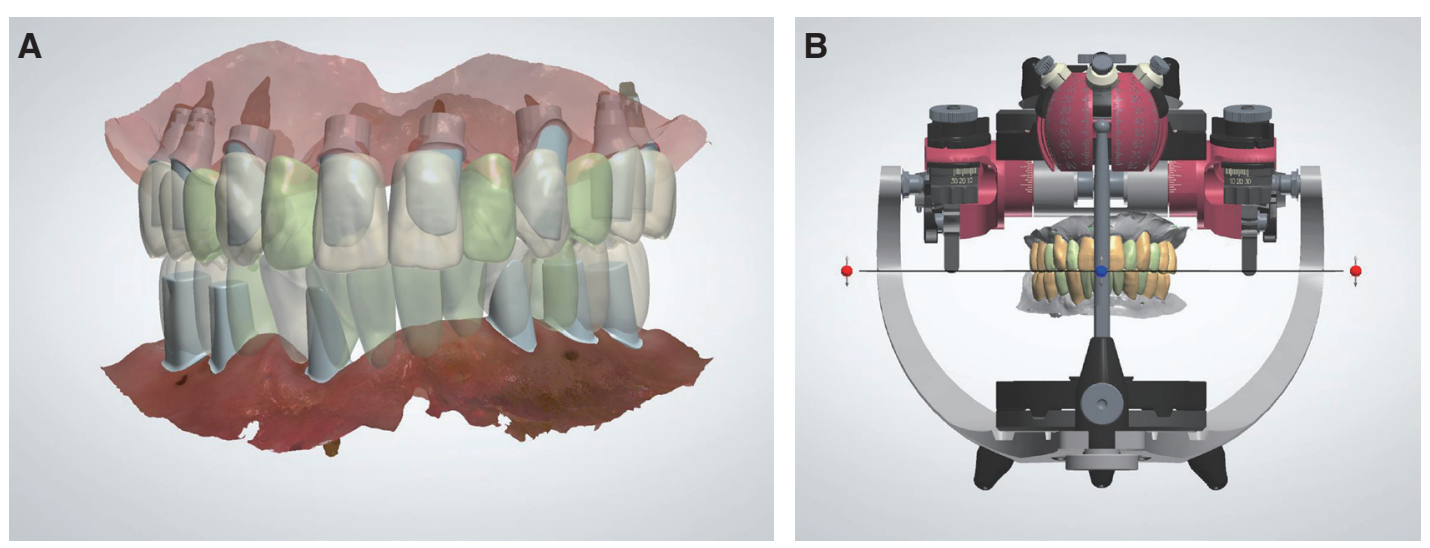

Fig. 10. Designing procedure of definitive prosthesis. (A) Definitive abutment and prosthesis design, (B) Positioning the definitive prosthesis on virtual articulator for occlusal adjustment.

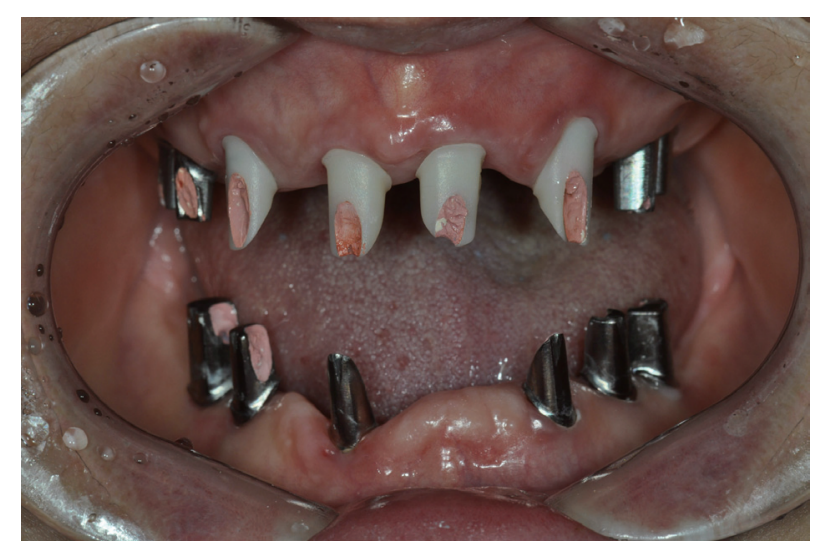

Fig. 11. Definitive customized abutment placement.

의 경우는 지대주와 보철물 간 마찰력이 과도한 경향 이 있었다. 레진 임시보철물의 경우 이미 중합이 완료 된 레진을 밀링하여 가공 후 수축이 없는 반면, 지르코 니아의 경우 밀링 후 소결과정에서 수축이 발생하기때 문에 최종보철물의 경우에는 레진 임시보철물과 적합도 에 있어서 차이가 있을 수 있다. 이와 같은 이유로 최종 보철물 제작 후, 내면 및 변연 적합도의 확인을 위해 지 대주 수준에서 인상채득을 결정하였다. Light body type (Kerr, Romulus, USA)과 putty type (DMG, Hamburg, Germany)의 실리콘 인상재를 이용하여 지대주 수준 에서 인상채득하고 석고모형을 제작하였으며, pattern resin으로 교합인기용 table을 제작하여 악간관계를 채 득하였다. 안궁이전과 악간관계기록을 이용하여 상 하 악 모형을 교합기에 부착하였다. 레진 임시보철물의 교 합, 안모 및 적합도가 적절하였기에 디자인의 수정없이 지르코니아를 밀링하여 최종보철물을 제작하였다. 색조 부여(shading), 소결 그리고 글레이징 과정을 거쳐 단일 구조 지르코니아 보철물 완성 후, 석고모형에서 보철물 의 적합도를 확인하였다(Fig. 12). 상악의 경우 매우 좋 은 적합도를 보였으며 하악의 경우에는 우측 구치부의 설측 부위에 2 - 3회 내면조정을 시행하였다.

최종보철물의 구내 시적 시, 상악의 적합도는 좋았으 며 하악은 지대주와 보철물 내면의 마찰력이 강한 편이 었으나 변연 적합도는 양호하였다(Fig. 13). 안모는 적절 하였으며(Fig. 14), 투명감은 부족했으나 전반적인 색조 는 만족스러웠다. 교합은 양측 구치부에 균등하게 중심 교합 형성하였고, 전방과 측방운동 시 상호보호교합을 확인하였다. 최종보철물 장착 후, $2-3$ 회에 걸쳐 교합조 정 시행하였으며, 3 개월 후까지 임플란트 주위의 골소 실은 관찰되지 않았고, 교합 역시 안정적으로 유지되었 다(Fig. 15). 

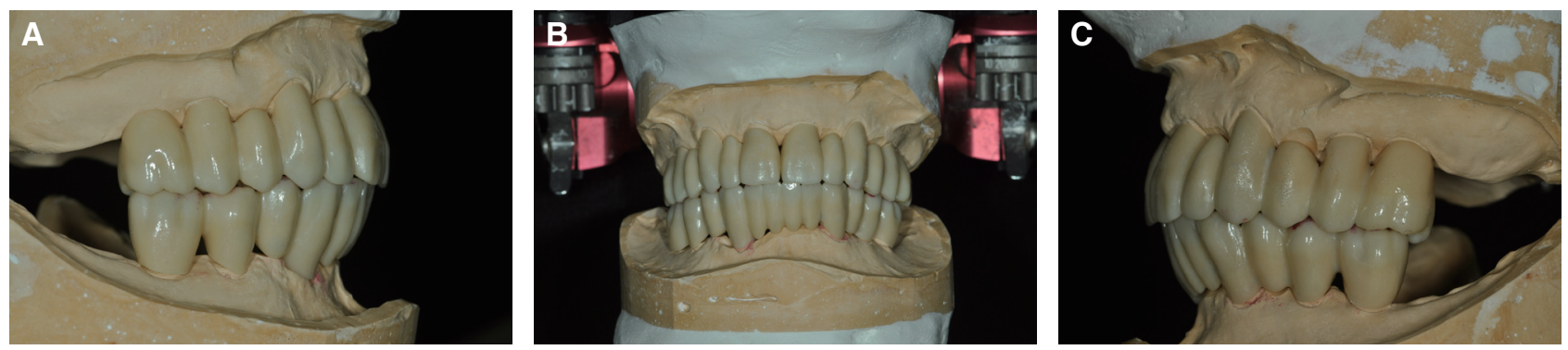

Fig. 12. Definitive prosthesis on stone cast.
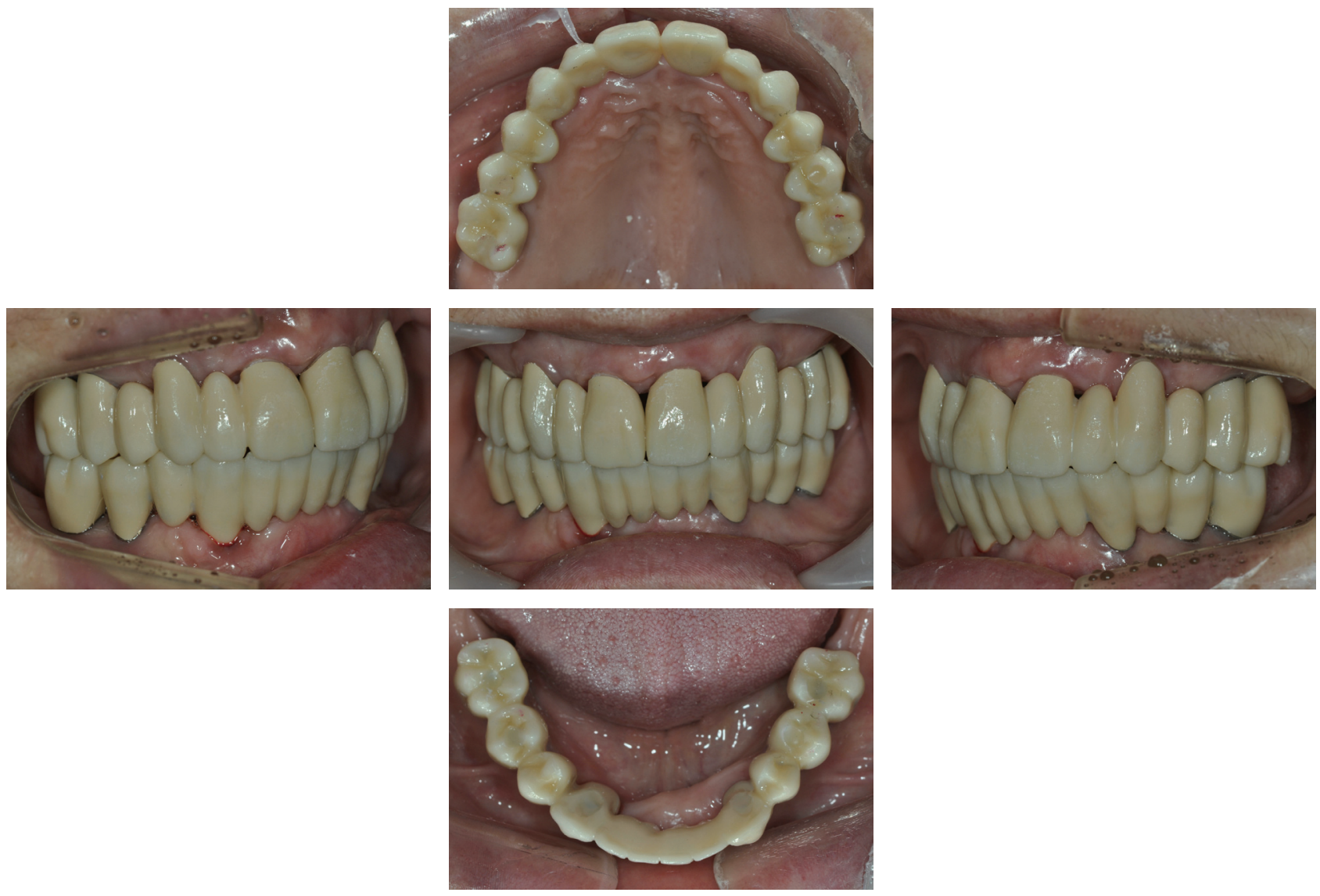

Fig. 13. Definitive prosthesis delivery.
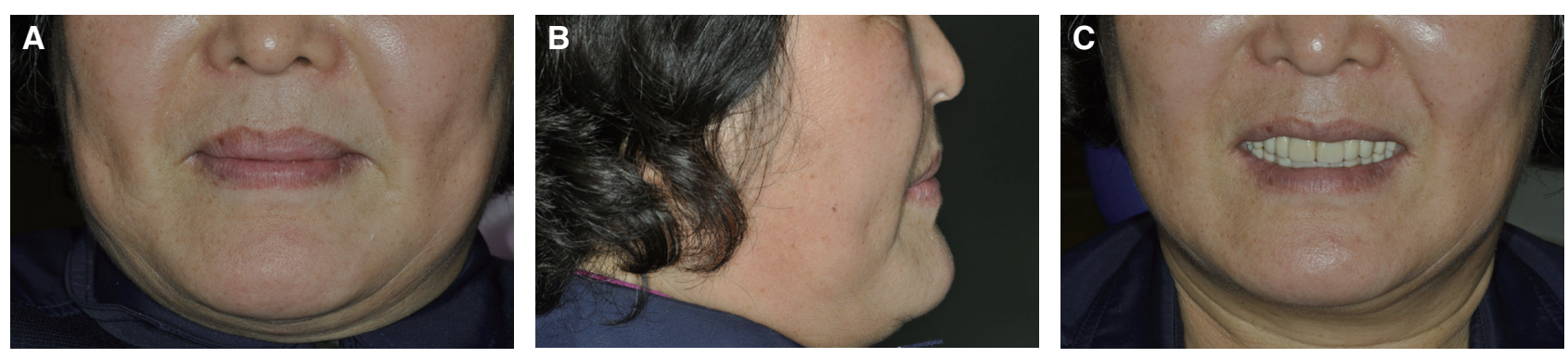

Fig. 14. Extraoral view after definitive prosthesis delivery. (A) Frontal view, (B) Lateral view, (C) Smile line. 


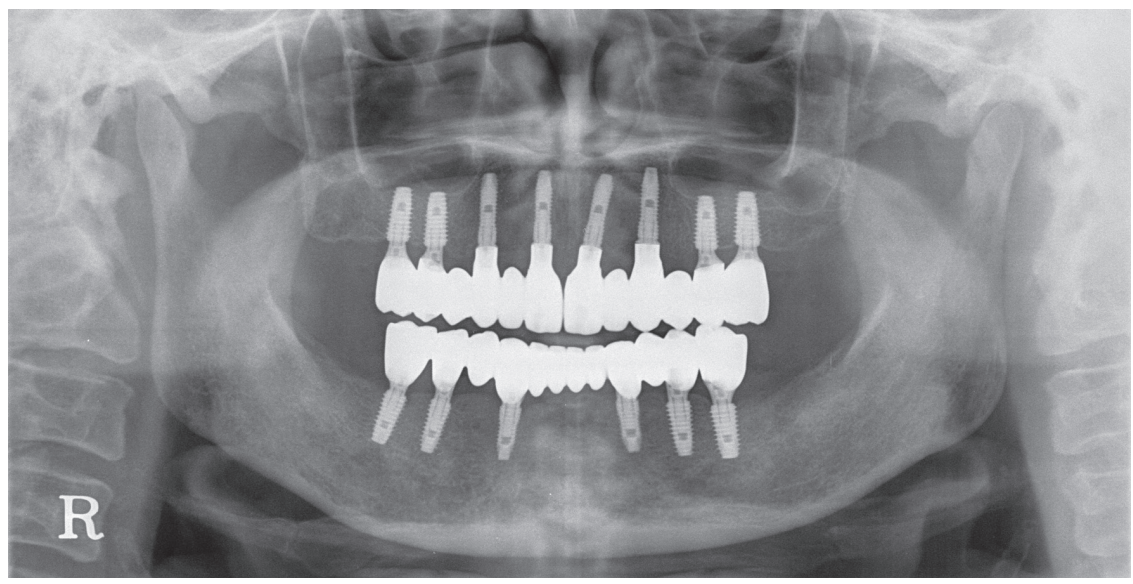

Fig. 15. Panoramic view after 3 months.

\section{고찰}

본 증례는 무치악 환자에서 방사선 불투과성 마커, 구 강스캐너, $\mathrm{CBCT}$ 를 활용하여 환자에게 적은 불편감을 주면서 정확한 위치에의 임플란트 식립과 보철수복의 방법을 제시하였다. 의치를 복제하여 방사선 및 수술용 스텐트를 제작하던 기존의 방식에 비해 환자의 내원 횟 수를 줄일 수 있으며 진료실 및 기공실 과정을 줄일 수 있었다. 또한 여러 단계의 수작업에서 발생하는 오차를 줄일 수 있으며, 디지털 이미지를 통해 다양한 진단 및 $\mathrm{CAD} / \mathrm{CAM}$ 작업이 가능하게 되었다. 본 증례에서 구강 스캔과 $\mathrm{CBCT}$ 촬영을 통해 얻은 두 개의 이미지를 통해 서 수술가이드, 맞춤형 지대주 및 보철물을 동시에 디자 인하고 제작하였는데, 이 과정을 위해서는 스캔 이미지 와 $\mathrm{CBCT}$ 이미지의 중첩이 필수적인 과정이다. 일반적 으로는 두 이미지에서 공통으로 보이는 치아를 이용하 여 중첩이 이루어지는데 무치악 환자의 경우에는 치아 를 기준으로 할 수 없다는 문제가 발생한다. 본 증례에 서 이러한 문제를 해결하기 위해 방사선 불투과성 마커 를 사용하였다. 마커는 무치악 뿐만 아니라 중첩할 치아 가 적은 경우나 많은 금속 보철물을 가지고 있어 CBCT 상에서 산란이 일어나는 경우에도 유용하게 적용할 수 있을 것으로 생각된다. 방사선 불투과성의 마커는 스캔 이미지와 CBCT 이미지 모두에서 선명하게 관찰되었으 며 이를 이용하여 두 이미지를 정확하게 중첩할 수 있었 다. 상악은 구개부에, 하악은 의치에 마커를 부착하였는 데 하악에서 의치를 이용한 이유는 첫째, 하악은 상악의 구개부처럼 마커를 붙일 수 있는 비가동성 조직부를 찾 기 어렵고, 둘째, 하악은 혀와 협점막의 방해로 직접적
으로 구강 내 스캔을 하기 매우 어렵기 때문이다. 또한, 완전 무치악 환자의 경우 대부분 의치를 사용하고 있으 며 이를 이용하여 안모, 수직교합고경, 악간관계, 치아배 열 등에 관한 많은 정보를 얻을 수 있다. 본 증례에서도 의치를 바탕으로 제작된 즉시보철물에서 매우 양호한 안모, 수직교합고경 및 교합을 보였다.

구강스캐너는 전악 혹은 정중선을 넘어가는 많은 부 위를 스캔 할 때 스캔과정에서 stitching 오차가 발생할 수 있는데, 그 주요원인으로 스캔과정에서 스캐너와 스 캔하려는 물체를 동시에 움직이는 경우를 생각할 수 있 다. 또한 스캔하는 캡쳐 수가 많아질수록 스캔 이미지의 stitching 오차가 누적되며 디지털 작업 시 속도저하와 오차를 만들게 된다. 즉 환자는 가급적 움직이지 않은 상태에서 가급적 적은 양의 캡쳐로 스캔을 진행해야 정 확한 스캔 이미지를 얻을 수 있다.

진단 및 계획 단계에서 모든 맞춤형 지대주를 치은 상 방 $0.5-1 \mathrm{~mm}$ 의 치은연상 변연으로 계획하였는데, 임플 란트 식립 및 맞춤형 지대주 체결 후, 하악의 2 개 지대주 에서 치은연하 변연이 관찰되었다. 이는 임플란트 식립 시 미세한 수직오차로 인한 것으로 생각되며, SCRP 형 태의 보철에서 시멘트 제거와 적절한 emergence profile 의 형성을 위해 지대주의 변연 위치를 치은 상방 $2 \mathrm{~mm}$ 정도로 설정하는 것이 적절할 것으로 생각된다. 최종보 철물의 제작은 3 차원 디지털 이미지만을 이용하여 이루 어졌는데, 상악의 경우는 적합도가 매우 좋았으나 하악 의 경우 $2-3$ 회의 내면조정이 필요했다. 상악은 2 분획으 로 나누어 보철물을 제작한 반면, 하악은 전악연결고정 을 시행한 부분에서 차이가 발생했을 수 있다. 구강스캐 너를 이용한 스캔시 정중선을 넘어가면서 오차가 커지 
게 되는데, 하악의 경우 전악을 연결고정함으로써 스캔 오차가 커진 것으로 생각된다. 또한, 하악의 mandibular flexure를 고려할 수 있다. 이는 하악을 크게 개구할 때 하악이 고정되어 있는 것이 아니라 주변근육들에 의해 휜다는 개념으로 전통적인 인상채득방법에 비해 구강스 캐너를 구내에 적용하려면 더 크게 입을 벌려야 하기 때 문에 본 증례에서 오차의 원인이 되었을 것으로 생각된 다. 본 증례에서 도재파절 등의 추후 합병증을 예방하기 위해 단일구조 지르코니아를 선택하였는데 단일구조 지 르코니아의 심미성은 기공사의 기술에 민감하며, 투명 도는 veneering 도재에 비해서는 부족한 실정이다. 따라 서 보철물의 강도 및 견고성과 심미성에서 상황에 맞는 중요도를 판별하여 결정하는 것이 필요할 것으로 생각 된다.

\section{결론}

치과에서 디지털 영역은 아직 시작단계라고 생각된 다. 하드웨어적으로 소프트웨어적으로도 해결하고 발전 시켜야 할 부분이 많고 그를 뒷받침해 줄 연구들이 필요 하다. 본 증례는 상 하악 무치악 환자의 전악 임플란트 수복에서 디지털 방법을 최대한으로 활용하고자 하였 다. 진단과정에서 중첩의 문제를 해결하고자 방사선 불 투과성 마커를 이용하였고, 이로 인해 방사선 스텐트의 제작과정을 생략하고, 정확도를 높일 수 있었다. 일련의 과정을 거쳐 제작된 수술가이드를 이용하여 상악 8 개, 하악 6개의 임플란트를 식립하였고 즉시보철물을 장착 하였다. 골유착 후 스캔바디를 이용하여 구강스캔하는 방식으로 맞춤형 최종지대주 및 최종보철물을 제작하 였으며, 안모, 교합, 적합도 등에서 양호한 결과를 얻었 다. 디지털과 $\mathrm{CAD} / \mathrm{CAM}$ 의 활용을 통한 임플란트 식립 과 보철물 제작을 통해 정확성, 환자와 술자의 편의성, 데이터의 활용 등 많은 장점을 확인할 수 있었다. 기존 의 전통적인 제작 방식과 비교해서는 안모나 악안면부 해부학적 위치에 대한 고려, 교합평면 등에 대한 추가적 연구가 필요할 것으로 생각된다.

\section{Orcid}

Se-Ha Kang http://orcid.org/0000-0002-1733-0319

Seung-Mi Jeong http://orcid.org/0000-0002-1543-7227

Jae-Ok Shin http://orcid.org/0000-0001-6229-9333
Jeong-Whan Fang http://orcid.org/0000-0002-6337-3088

Dae-Hwan Kim http://orcid.org/0000-0003-4466-5170

Byung-Ho Choi http://orcid.org/0000-0002-6105-6118

\section{References}

1. Seitz H, Tille C, Irsen S, Bermes G, Sader R, Zeihofer HF. Rapid Prototyping models for surgical planning with hard and soft tissue representation. Int Congress Series 2004;1268:567-72.

2. Ganz SD. Use of stereolithographic models as diagnostic and restorative aids for predictable immediate loading of implants. Pract Proced Aesthet Dent 2003;15:763-71.

3. Hajeer MY, Millett DT, Ayoub AF, Siebert JP. Applications of 3D imaging in orthodontics: part II. J Orthod 2004;31:154-62.

4. Di Giacomo GA, Cury PR, de Araujo NS, Sendyk WR, Sendyk CL. Clinical application of stereolithographic surgical guides for implant placement: preliminary results. J Periodontol 2005;76:503-7.

5. Ruppin J, Popovic A, Strauss M, Spüntrup E, Steiner A, Stoll C. Evaluation of the accuracy of three different computer-aided surgery systems in dental implantology: optical tracking vs. stereolithographic splint systems. Clin Oral Implants Res 2008;19:70916.

6. Van Assche N, van Steenberghe D, Guerrero ME, Hirsch E, Schutyser F, Quirynen M, Jacobs R. Accuracy of implant placement based on pre-surgical planning of three-dimensional cone beam images: a pilot study. J Clin Periodontol 2007;34:816-21.

7. van Steenberghe D, Naert I, Andersson M, Brajnovic I, Van Cleynenbreugel J, Suetens P. A custom template and definitive prosthesis allowing immediate implant loading in the maxilla: a clinical report. Int J Oral Maxillofac Implants 2002;17:663-70.

8. Kim KS, Lim YJ, Kim MJ, Kwon HB, Yang JH, Lee $\mathrm{JB}$, Yim SH. Variation in the total lengths of abutment/implant assemblies generated with a function of applied tightening torque in external and internal implant-abutment connection. Clin Oral Implants Res 2011;22:834-9. 


\section{3차원 디지털 영상과 CAD/CAM 시스템을 활용한 전악 임플란트 수복 증례}

\section{강세하 ${ }^{1}$, 정승미 ${ }^{1 *}$, 신재옥 ${ }^{1}$, 방정환 $^{1}$, 김대환 $^{1}$, 최병호 $^{2}$}

${ }^{1}$ 연세대학교 원주의대 치과보철과

${ }^{2}$ 연세대학교 원주의대 구강악안면외과

본 증례는 상 하악 완전 무치악 환자에서 진단, 식립 그리고 보철물 제작에 디지털 방식을 활용하는 방법에 대해 제시 하였다. 상악은 구개 부위, 하악은 기존 의치에 방사선 불투과성 마커를 부착한 후 구강스캔 및 $\mathrm{CBCT}$ 촬영을 시행하였 다. 구강스캔 이미지와 $\mathrm{CBCT}$ 이미지를 중첩시켜 진단 및 수술가이드와 임시보철물을 제작하였다. 골유착 후에는 스캔 바디를 이용한 구강스캔을 통해 최종보철물을 제작하였다. 임플란트를 이용한 전악수복에서 디지털 방식을 다양하게 활용하였으며 정확성과 환자의 불편감 최소화라는 목적에 만족할만한 결과를 얻었기에 이 증례를 보고하고자 한다.

(구강회복응용과학지 2015;31 (2):158-68)

주요어: 무치악; 전악수복; $\mathrm{CAD} / \mathrm{CAM}$; 무절개 임플란트; 구강스캔; 디지털 시스템 